\title{
Integrating Data Mining, Network Pharmacology, and Molecular Docking Verification to Investigate the Molecular Mechanism of Traditional Chinese Medicine Prescriptions for Treating Male Infertility
}

Research Article

Keywords:

Posted Date: March 18th, 2021

DOI: https://doi.org/10.21203/rs.3.rs-264555/v2

License: (1) This work is licensed under a Creative Commons Attribution 4.0 International License. Read Full License 


\section{Abstract}

The authors have requested that this preprint be withdrawn due to erroneous posting.

\section{Full Text}

The authors have withdrawn this preprint from Research Square. 